\title{
PENINGKATAN INTERAKSI BELAJAR KALKULUS DIFERENSIAL DENGAN MENGGUNAKAN MODEL PEMBELAJARAN TIPE TEAM ASSISTED INDIVIDUALLY (TAI) PADA MAHASISWA PENDIDIKAN MATEMATIKA
}

\author{
Sumargiyani \\ Pendidikan Matematika FKIP Universitas Ahmad Dahlan \\ sumargiyani04@yahoo.com
}

\begin{abstract}
This research aims to improve the learning interaction of the students of Mathematics Education Study Program of FKIP UAD Yogyakarta in Differential Calculus subject in the academic year 2015/2016 using the cooperative learning model of Team Assisted Individually (TAI) type. This research is a class action research conducted within three cycles. The research subject is the student class $C$ of Mathematics Education Study Program of FKIP UAD in the academic year 2015/2016 taking Calculus Differential subject. The research object is the implementation of the learning using the cooperative learning model of TAI type in Calculus Differential subject conducted in the student class $C$ of Mathematics Education Study Program of FKIP UAD in the academic year 2015/2016. The data are collected by observation, interview, and test method. The data analysis used is qualitative descriptive analysis. The research results show that the learning using the cooperative learning model of TAI type can improve the Differential Calculus learning interaction of the students of Mathematics Education Study Program of FKIP UAD in the academic year 2015/2016. It is shown by the observation results of Differential Calculus learning interaction average, those are 53,45\% (fair), 71,27\% (good), and 80,07\% (very good) in cycle I, II, and III, respectively.
\end{abstract}

Keywords : interaction, learning model, TAI.

\begin{abstract}
ABSTRAK. Penelitian ini bertujuan untuk meningkatkan interaksi belajar Kalkulus Diferensial dengan menggunakan model pembelajaran kooperatif tipe Team Assisted Individually (TAI) mahasiswa Program Studi Pendidikan Matematika FKIP UAD Yogyakarta Tahun Akademik 2015/2016. Penelitian ini merupakan penelitian tindakan kelas yang dilakukan sebanyak tiga siklus. Subjek dalam penelitian mahasiswa kelas C program studi Pendidikan Matematika FKIP UAD TA 2015/2016 yang mengambil mata kuliah Kalkulus Diferensial. Sedangkan objek penelitian adalah penerapan pembelajaran dengan model pembelajaran kooperatif tipe TAI pada mata kuliah Kalkulus Diferensial pada mahasiswa kelas C Program Studi Pendidikan Matematika FKIP UAD TA 2015/2016. Data dikumpulkan dengan metode observasi, wawancara dan tes. Analisis data yang digunakan adalah analisis deskriptif kualitatif. Hasil penelitian menunjukkan bahwa pembelajaran dengan model pembelajaran kooperatif tipe TAI dapat meningkatkan interaksi belajar Kalkulus Diferensial mahasiswa Program Studi Pendidikan Matematika FKIP UAD TA 2015/2016. Hal ini terbukti dari hasil observasi rata-rata interaksi belajar Kalkulus Diferensial pada Siklus I sebesar 53.45\%(kriteria cukup), meningkat pada
\end{abstract}


Siklus II $71.27 \%$ (kriteria baik). Pada Siklus III meningkat sebesar $80.07 \%$ (kriteria sangat baik).

Kata kunci : interaksi, model pembelajaran, TAI.

\section{PENDAHULUAN}

Kalkulus Diferensial merupakan salah satu mata kuliah yang diajarkan di Pendidikan Matematika FKIP UAD. Kalkulus Diferensial merupakan salah satu mata kuliah yang dijadikan prasyarat untuk mengambil beberapa mata kuliah, seperti Kalkulus Integral dan Kalkulus Lanjut. Kalkulus Difrensial membahas berbagai macam materi diantaranya : fungsi, limit fungsi, kontinuitas, turunan dan aplikasi turunan. Jika dilihat dari hasil belajar yang diperoleh mahasiswa pada mata kuliah Kalkulus Diferensial menunjukkan hasil belajar belum optimal. Hasil belajar yang diperoleh mahasiswa tidak terlepas dari proses belajar yang dilakukan mahasiswa dan proses mengajar dosen yang dilakukan di kelas. Dalam proses belajar mengajar dalam Nana Sudjana (2012:2) mengandung tiga unsur yang dapat dibedakan, yakni tujuan pengajaran (instruksional), pengalaman (proses) belajar-mengajar, dan hasil belajar. Untuk mencapai keberhasilan belajar mengajar di kelas dipengaruhi oleh banyak komponen. Menurut Syaiful Bahri Djamarah dan Aswan Zain (2010: 41) komponen kegiatan belajar mengajar meliputi "Tujuan, bahan pelajaran, kegiatan belajar mengajar, metode, alat dan sumber, serta evaluasi”.

Untuk mencapai hasil belajar yang optimal, sebelum melaksanakan pembelajaran harus membuat suatu perencanaan yang matang. Hal ini seperti yang diungkap Degeng dalam Jamil Suprihatiningrum (2013:109) mengatakan bahwa bagi para pengembang dan pelaksana pembelajaran, merencanakan pembelajaran dengan baik merupakan sebagian besar keberhasilan pembelajaran. Dalam pengertian ini secara implisit dapat dipahami bahwa kegiatan memilih, menetapkan, mengembangkan metode merupakan salah satu upaya yang harus dilakukan pengajar untuk mencapai kebehasilan dalam pembelajaran.

Variasi dan inovasi model pembelajaran perlu dilakukan oleh pengajar untuk mengurangi kejenuhan dan kebosanan mahasiswa dalam belajar di kelas. 
Salah satu model pembelajaran yang dapat diterapkan adalah model pembelajaran kooperatif. "Model pembelajaran adalah pola yang digunakan sebagai pedoman dalam merencanakan pembelajaran di kelas maupun tutorial” (Agus Suprijono,2012:46).“Pembelajaran kooperatif adalah konsep yang lebih luas meliputi semua jenis kerja kelompok termasuk bentuk-bentuk yang lebih dipimpin oleh guru atau diarahkan oleh guru" (Agus Suprijono, 2012:54). Salah satu model pembelajaran kooperatif adalah model pembelajaran kooperatif tipe Team Assisted Individually (TAI). Model pembelajaran kooperatif tipe TAI menurut Robert E Slavin dalam Miftahul Huda,(2014:200) "TAI merupakan sebuah program pedagogik yang berusaha mengadaptasikan pembelajaran dengan perbedaan individual siswa secara akademik" Model pembelajaran tipe TAI memiliki 8 tahapan dalam pelaksanaannya, yaitu (1) Placement test; (2) Teams; (3) Teaching group; (4) Student Creative; (5) Team Study; (6) Fact Test; (7) Team Score dan Team Recognition; (8) Whole Class unit.

Model pembelajaran tipe TAI yang termasuk model pembelajaran kooperatif, dapat dipilih sebagai variasi pembelajaran untuk meningkatkan hasil belajar Kalkulus. Seperti yang dilakukan Shofia Endriati (2014) menunjukkan dengan menggunakan model pembelajaran kooperatif tipe TAI mahasiswa memiliki kemampuan Kalkulus 1 yang lebih dibanding yang mengikuti pembelajaran biasa. Berdasarkan hasil penelitian Husni Sabil (2014) dengan menerapkan model pembelajaran kooperatif diperoleh hasil aktivitas mahasiswa terjadi peningkatan, selain itu dari model pembelajaran kooperatif yang diterapkan dapat meningkatkan hasil belajar mahasiswa, yaitu dengan nilai rata-rata 78 . Ketuntasan secara klasikal yang diperoleh mahasiswa mencapai 88,24\%. Dari kedua hasil penelitian tersebut dapat dipahami bahwa dengan menerapkan model pembelajaran kooperatif tipe TAI pada mata kuliah Kalkulus dapat meningkatkan aktivitas dan hasil belajar dibanding dengan menerapkan pembelajaran biasa. Oleh karena berdasarkan teori interaksi belajar merupakan bagian dari aktivitas belajar, maka dengan meningkatknya aktivitas belajar kemungkinan besar interaksi belajarnya juga meningkat. 
Interaksi belajar merupakan bagian dari aktivitas belajar. " Interaksi belajar mengajar adalah hubungan timbal balik antara guru (pengajar) dan anak (murid) yang menunjukkan adanya hubungan yang bersifat edukatif'. Soetomo (1993: 9-10) "Dari kegiatan interaksi mengajar belajar, guru membelajarkan siswa dengan harapan bahwa siswa belajar" (Dimyati dan Mudjiono:2006:25). Hubungan yang dilakukan antara dosen dengan mahasiswa ataupun hubungan antar mahasiswa dapat dilakukan dalam suatu proses pembelajaran di kelas. Interaksi ini dilakukan untuk memperoleh hasil belajar mahasiswa yang optimal. Dalam peraturan Pemerintah Republik Indonesia Nomor 32 Tahun 2013 Pasal 1 ayat 19 disebutkan bahwa "Pembelajaran adalah proses interaksi antar peserta didik, antara peserta didik dengan pendidik dan sumber belajar pada suatu lingkungan belajar".

Dari tahapan yang ada pada penerapan pembelajaran dengan model pembelajaran kooperatif tipe TAI, kemampuan awal yang dimiliki mahasiswa Pendidikan Matematika UAD dan kajian teori interaksi belajar, maka peneliti merujuk indikator untuk interaksi belajar yang diamati yaitu: (a) Interaksi dosen dengan mahasiswa, (b) Interaksi antar mahasiswa dan (c) Interaksi mahasiswa dengan sumber belajar.

Penelitian yang bertujuan untuk meningkatkan interaksi belajar Kalkulus Diferensial dengan menggunakan model pembelajaran kooperatif tipe TAI mahasiswa pendidikan Matematika FKIP UAD Tahun akademik 2015/2016, secara teoritis diharapkan dapat memberikan sumbangan dalam pembelajaran Kalkulus Diferensial, terutama untuk mendapatkan hasil belajar Kalkulus Diferensial mahasiswa melalu model pembelaaran kooperatif tipe TAI dan manfaat secara praktis dapat memberikan dorongan kepada peneliti dalam memperbaiki dan meningkatkan kualitas pembelajaran salah satunya dengan model pembelajaran yang variatif.yaitu model pembelajaran kooperatif tipe TAI.

\section{METODE PENELITIAN}

Penelitian ini dilaksanakan di Program Studi Pendidikan Matematika FKIP Universitas Ahmad Dahlan pada semester genap Tahun Akademik 1015/2016. 
Subjek penelitian ini adalah mahasiswa kelas $\mathrm{C}$ yang menempuh mata kuliah Kalkulus Diferensial program studi Pendidikan Matematika Universitas Ahmad Dahan Yogyakarta Tahun Akademik 2015/2016 sebanyak 60 mahasiswa. Obyek penelitian ini adalah keseluruhan proses pembelajaran dengan model pembelajaran kooperatif tipe TAI, dan interaksi belajar mahsiswa dalam perkuliahan mata kuliah tersebut. Jenis penelitian yang dilakukan Penelitian Tindakan Kelas (PTK) atau Clasroom Action Research (CAR) yang dilakukan ini mencakup empat langkah yakni : planning, acting, observing dan reflecting (H.E Mulyasa. 2011:112). Prosedur penelitian tindakan kelas dilaksanakan dalam tiga siklus dengan Siklus I dan II dua kali pertemuan dan Siklus III satu kali pertemuan. Instrumen pengumpulan data meliputi : tes yang berbentuk uraian, lembar observasi, dan pedoman wawancara. Tes disusun dalam bentuk soal uraian, sesuai materi kuliah Kalkulus Diferensial yang telah diberikan. Teknik pengumpulan data ada 3 yaitu : wawancara, tes dan observasi. Wawancara dilakukan oleh observer terhadap beberapa mahasiswa per pertemuan, dilakukan dengan mengacu pedoman wawancara yang telah disediakan. Tes individu dilakukan di akhir siklus dalam bentuk tes uraian. Analisis data yang dilakukan meliputi : analisis data observasi, analisis data ulangan, reduksi data, triangulasi, display data, dan penarikan kesimpulan. Indikator keberhasilan penelitian ini ditandai dengan adanya perubahan ke arah perbaikan, baik terkait pelaksanaan pembelajaran maupun hasil pembelajaran. Indikator dari keberhasilan penelitian ini adalah:

a. Meningkatnya interaksi belajar mahasiswa dalam pembelajaran Kalkulus Diferensial pada materi fungsi, grafik fungsi, limit fungsi dan kontinuitas. Peningkatan interaksi belajar mahasiswa tersebut ditandai dengan meningkatnya setiap indikator pada setiap siklus.

b. Penelitian disebut berhasil jika interaksi belajar mahasiswa telah mencapai kriteria sangat baik. 


\section{HASIL DAN PEMBAHASAN}

\subsection{Hasil}

Pelaksanaan kegiatan pembelajaran dilakukan dalam lima kali pertemuan. Siklus pertama dua kali pertemuan, siklus kedua dua kali pertemuan dan siklus ketiga satu kali pertemuan. Selama kegiatan pembelajaran Kalkulus Diferensial dilaksanakan dengan menggunakan model pembelajaran kooperatif tipe TAI telah dilakukan pengamatan interaksi belajar mahasiswa. Dari tiga siklus yang dilakukan diperoleh hasil sebagai berikut :

Tabel 1. Hasil Observasi Interaksi Belajar Kalkulus Diferensial Siklus I,II dan III

\begin{tabular}{ccccc}
\hline & \multicolumn{1}{c}{ Indikator/aspek } & \multicolumn{2}{c}{ SIKLUS } \\
\cline { 3 - 5 } & \multicolumn{1}{c}{1} & 2 & 3 \\
\hline 1. Interaksi mahasiswa dengan dosen & $61,12 \%$ & $75,23 \%$ & $93,64 \%$ \\
\hline 2. Interaksi mahasiswa dengan mahasiswa & $43,76 \%$ & $71,88 \%$ & $75,00 \%$ \\
\hline 3. & $\begin{array}{l}\text { Interaksi mahasiswa dengan sumber } \\
\text { belajar }\end{array}$ & $61,28 \%$ & $88,39 \%$ & $95,76 \%$ \\
\hline & Interaksi belajar per siklus : & $50,28 \%$ & $71,13 \%$ & $80,15 \%$ \\
\hline
\end{tabular}

Hasil rata-rata persentase interaksi belajar mahasiswa pada Tabel 1, selanjutnya dikriteriakan atau dikategorikan dengan menggunakan tabel berikut :

Tabel 2. Kualitatif Hasil Lembar Obsevasi Mahasiswa

\begin{tabular}{cc}
\hline Presentase & Kriteria \\
\hline $80 \%<\mathrm{P} \leq 100 \%$ & Sangat Baik \\
$60 \%<\mathrm{P} \leq 80 \%$ & Baik \\
$40 \%<\mathrm{P} \leq 60 \%$ & Cukup \\
$20 \%<\mathrm{P} \leq 40 \%$ & Kurang \\
$0 \% \leq \mathrm{P} \leq 20 \%$ & Kurang sekali \\
\hline
\end{tabular}

Setelah data dikategorikan sesuai Tabel 2. Diperoleh hasil pada Siklus I persentase interaksi belajar mahasiswa sebesar 50,28\% termasuk kategori cukup, pada Siklus II persentase interaksi belajar mahasiswa sebesar $71,13 \%$ termasuk kategori baik dan pada Siklus III sebesar 80,15\% termasuk kategori sangat baik. 
Secara grafik persentase interaksi belajar mahasiswa persiklusnya dapat digambarkan sebagai berikut :

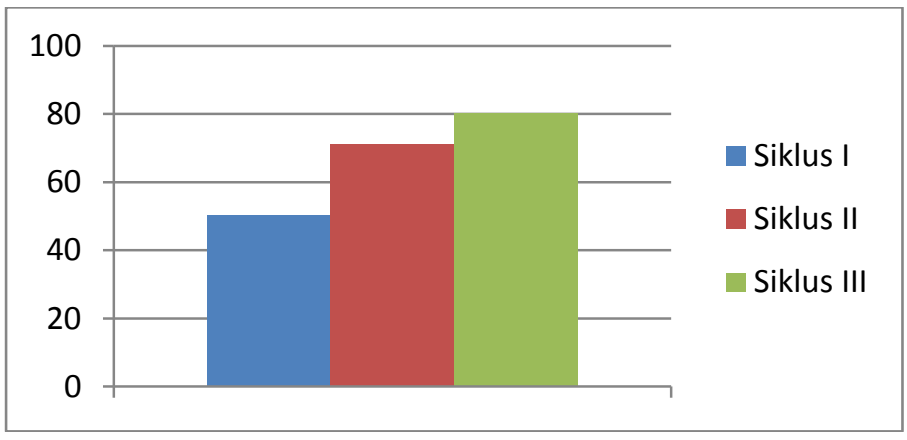

Gambar 1. Grafik Persentase Interaksi Belajar Kalkulus Diferensial Mahasiswa Siklus I, Siklus II dan Siklus III

Jika dilihat perindikatornya, dari Siklus I, Siklus II dan Siklus III juga mengalami peningkatan, Hal ini dapat dilihat dari hasil observasi interaksi belajar Kalkulus Diferensial yang dapat disajikan dalam grafik berikut ini :

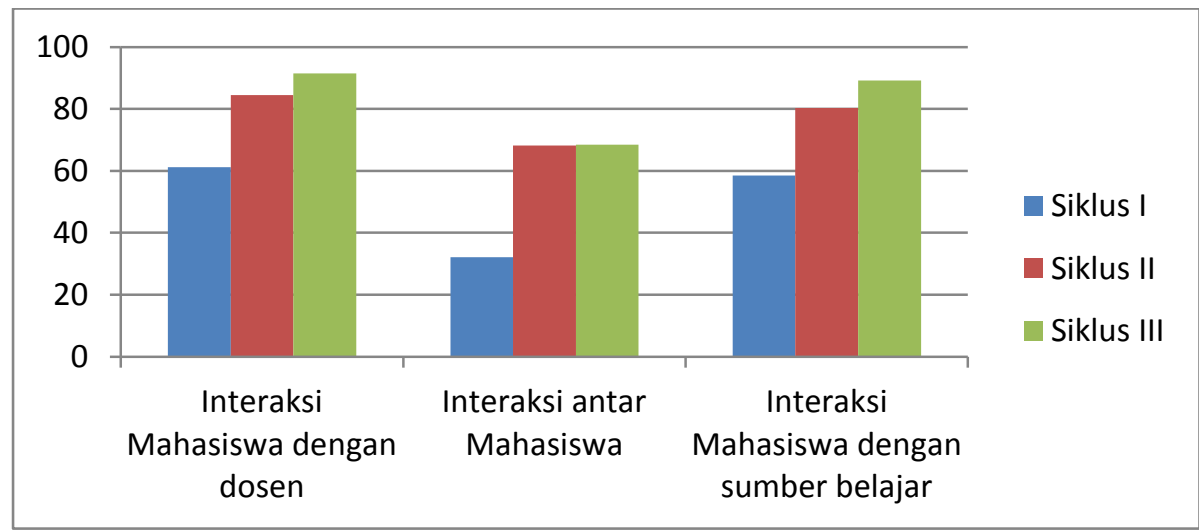

Gambar 2. Grafik Interaksi Belajar Kalkulus Diferensial Mahasiswa Per indikator Pada Siklus I, Siklus II dan Siklus II

Dari grafik di atas terlihat bahwa interaksi belajar Kalkulus Diferensial mahasiswa perindikatornya telah mengalami kenaikan pada tiap siklusnya. Kenaikan yang sangat pesat terjadi pada indikator interaksi antar mahasiswa, yaitu pada Siklus I dengan kriteria cukup meningkat menjadi kriteria sangat baik pada Siklus II. 


\subsection{Pembahasan}

Hasil penelitian tindakan kelas ini yang dilaksanakan dalam tiga siklus, dengan menerapkan model pembelajaran kooperatif tipe TAI telah diperoleh hasil interaksi belajar Kalkulus Diferensial mahasiswa mengalami peningkatan per siklusnya.

Siklus I. Pada Siklus I dilakukan dalam dua kali pertemuan, dengan alokasi waktu perpertemuan 3X50'. Materi yang dibahas fungsi dan grafik fungsi. Pada pertemuan pertama Siklus I, peneliti melakukan persiapan dengan membuat RPP, lembar observasi, pedoman wawancara, kuis, LKM dan soal tes. Pelaksanaan kegiatan pembelajaran sesuai dengan langkah-langkah model pembelajaran kooperatif tipe TAI. Dalam pelaksanaan kegiatan dibantu oleh lima orang observer, yang bertugas mengobservasi interaksi belajar mahasiswa selama proses pembelajaran dan mewawancari beberapa mahasiswa setelah kegiatan pembelajaran berlangsung. Setelah mendapatkan data, dilakukan analisis data dan diperoleh kesimpulan bahwa pada Siklus I aspek yang masih dalam kriteria cukup meliputi : (a) Mahasiswa bertanya pada dosen, (b) Mahasiswa bertanya maupun menjawab pertanyaan teman dari kelompok lain, dan (c) Mahasiswa membaca materi dari buku atau internet. Ketiga aspek tersebut masih dalam kriteria cukup, setelah peneliti klarifikasi dengan melakukan wawancara dengan beberapa mahasiswa terkait dengan ketiga aspek di atas, dapat disimpulkan bahwa (a). Mahasiswa sudah paham dengan materi yang dijelaskan oleh dosen, sehingga mahasiswa tidak perlu menanyakan materi yang belum dipahami atau meminta penjelasan dari dosen, (b). Mahasiswa tidak bertanya dengan kelompok lain, karena mahasiswa sudah bisa memecahkan permasalahan dengan kelompoknya sendiri tanpa minta bantuan (bertanya) dengan kelompok lain dan (c) Mahasiswa telah membaca materi dari buku ataupun internet sebelum dosen menjelaskan, akan tetapi ketika latihan mengerjakan soal, mahasiswa tidak membuka catatan kembali karena sudah dapat menyelesaikan soal tanpa melihat catatan. Oleh karena itu interaksi mahasiswa dengan sumber belajar dalam krteria cukup.

Siklus II. Pada Siklus II ini masih menerapkan model pembelajaran kooperatif tipe TAI. Dari hasil refleksi pada Siklus I dilakukan perbaikan- 
perbaikan pada Siklus II. Perencanaan pada Siklus II ini, peneliti mempersiapkan RPP, LKM, soal tes, lembar observasi dan pedoman wawancara. Pelaksanaan kegiatan pembelajaran dilakukan dua kali pertemuan, dengan masing-masing pertemuan 3x50'. Materi yang dibahas pada pertemuan ini Limit fungsi. Kegiatan pembelajaran berlangsung lebih aktif dibanding pada Siklus I. Dalam pelaksanaan kegiatan, peneliti dibantu oleh lima orang observer yang bertugas mengobservasi interaksi belajar mahasiswa selama kegiatan pembelajarn berlangsung. Di akhir pembelajaran dilakukan wawancara dengan beberapa mahasiswa terkait interaksi belajar dan keterlaksanaan pembelajaran model TAI. Data dari hasil obervasi dan wawancara dilakukan analisis yang menghasilkan kesimpulan : (a) Aspek mahasiswa bertanya pada dosen masih dalam kriteria cukup. Aspek ini, belum mengalami kenaikan dari Siklus I, setelah peneliti mengklarifikasi dengan beberapa mahasiswa, mereka tidak mengajukan pertanyaan ke dosen karena mahasiswa sudah paham dengan penjelasan dosen sehingga tidak ada yang perlu ditanyakan. Untuk menegaskan kembali, apakah mahasiswa sudah paham dengan materi yang dijelaskan, dosen memberi beberapa pertanyaan. Hasilnya mahasiswa dapat menjawab pertanyaan dengan benar. (b) Aspek mahasiswa bertanya pada teman dalam kelompok lain dengan kriteria cukup. Hal ini dikarenakan mahasiswa tidak mengalami kesulitan dalam memahami materi sehingga tidak perlu bertanya ke kelompok lain. Interaksi dengan teman dalam satu kelompoknya telah terjadi peningkatan. Setelaha peneliti cek dengan hasil pekerjaan kelompok, mahasiswa sudah mengerjakan dengan benar. Hal ini, menunjukkan salah satu indikasi bahwa mahasiswa tidak bertanya dengan kelompok lain karena sudah dapat mengerjakan soal dengan teman satu kelompok. Hasil interaksi belajar mahasiswa pada Siklus II ada peningkatan dibanding dengan Siklus I.

Siklus III. Pada Siklus III persiapan peneliti sama dengan siklus sebelumnya. Pertemuan pada Siklus III ini dilakukan dalam satu kali pertemuan 3x50'. Materi yang dibahas kontinuitas. Dari hasil temuan pada Siklus II dilakukan perbaikan-perbaikan pada Siklus III. Hasil dari Siklus III ini aspek yang masih dalam kriteria cukup adalah mahasiswa bertanya pada teman dalam kelompok lain. Aspek ini tidak terjadi peningkatan dikarenakan kerjasama atau 
interaksi mahasiswa dalam satu kelompoknya telah mengalami kenaikan. Artinya permasalahan yang mahasiswa hadapi telah terselesaikan di kelompoknya sendiri, sehingga tidak memerlukan bantuan kelompok lain.

Secara keseluruhan dapat disimpulkan bahwa pembelajaran dengan menggunakan model pembelajaran kooperatif tipe TAI dapat digunakan sebagai upaya untuk meningkatkan interaksi belajar Kalkulus Diferensial mahasiswa Program Studi Pendidikan Matematika FKIP UAD Tahun Akademik 2015/2016. Hasil ini sesuai dengan hasil- hasil penelitian yang telah dilakukan oleh penelitipeneliti lain, yang menunjukkan dengan menggunakan model pembelajaran kooperatif tipe TAI mahasiswa memiliki kemampuan Kalkulus 1 yang lebih dibanding yang mengikuti pembelajaran biasa.

\section{KESIMPULAN}

Dari hasil penelitian dapat disimpulkan bahwa model pembelajaran kooperatif tipe TAI dapat meningkatan interaksi belajar Kalkulus Diferensial mahasiswa kelas C Program Studi Pendidikan Matematika FKIP UAD Tahun Akademik 2015/2016 pada materi fungsi, grafik fungsi, limit fungsi dan kontinuitas. Hal ini dapat dilihat dari persentase interaksi belajar per siklusnya mengalami peningkatan.

\section{DAFTAR PUSTAKA}

Dimyati dan Mudjiono, Belajar dan Pembelajaran, P.T. Rineka Cipta, 2006.

Djamarah, S. B. dan Zain, A., Strategi Belajar Mengajar, P.T. Rineka Cipta, 2010.

Mulyasa, H. E., Praktik Penelitian Tindakan Kelas, P.T. Remaja Rosdakarya, Bandung, 2010.

Huda, M., Model-model Pengajaran dan Pembelajaran, Pustaka Pelajar, 2014.

Riduwan, Dasar-dasar Statistika, Alfabeta, 2011.

Sabil, H., Meningkatkan Hasil Belajar Melalui Pembelajaran Kooperatif Tipe Think-Pair-Share Pada Materi Penampang dan Jaring-Jaring Mahasiswa, Edumatika, 4(1) (2014), 30-36. 
Endriati, S., Penerapan Pembelajaran Kooperatif Tipe Team Assisted Indiviualization (TAI) untuk Meningkatkan Kemampuan Kalkulus I., http://download.portalgaruda.org/article.php?article=4409148\&val=7613 \&title=PENERAPAN\%20OPE, diakses pada 30 November 2016.

Soetomo, Dasar-dasar Interaksi Belajar Mengajar, Usaha Nasional, 1993.

Sujana, N., Penilaian Hasil Proses Belajar Mengajar, P.T. Remadja Rosdakarya, 2012.

Suprihatiningrum, J., Strategi Pembelajaran Teori dan Aplikasinya, Ar Ruzz Media, 2013.

Suprijono, A., Cooperative Learning Teori dan Aplikasi PAIKEM, Pustaka Pelajar, 2012 
